\title{
500 - rocznica kanonizacji św. Elizeusza Ławryszowskiego na soborze w Wilnie w 1514 roku
}

\author{
Antoni Mironowicz \\ Katedra Historii Europy Środkowo-Wschodniej, Uniwersytet w Białymstoku \\ Polska \\ amir@uwb.edu.pl
}

\begin{abstract}
Antoni Mironowicz, 500 anniversary of the canonization of a Saint Elizeusz Lavryshevski in council of Vilnius in 1514, Elpis, 172015 :
\end{abstract} $37-41$.

\begin{abstract}
Council of Vilnius, in 1514, greatly improved the functioning and internal organization of the Orthodox Church and strengthened the discipline and moral state of the Ruthenian clergy. The council of 1514 canonized Elizeusz Lavryshevski and this new development of his canonization led to his worship among the faithful of the Orthodox Church throughout the Grand Duchy of Lithuania.
\end{abstract}

Streszczenie: Sobór prawosławny w Wilnie kanonizował w 1514 roku Elizeusza Ławryszewskiego i przez tę kanonizację doprowadził do rozwoju jego kultu na całym obszarze Wielkiego Księstwa Litewskiego.

Keywords: Saint Elizeusz Lavryshevski, Orthodox Church

Słowa kluczowe: św. Elizeusz Ławryszowski, Kościół prawosławny

Na kolejnym synodzie odbywającym się w Wilnie od 2 do 5 lutego 1514 roku dominowały sprawy wewnątrzcerkiewne i problem kanonizacji Elizeusza Ławryszewskiego ${ }^{1}$. Metropolita Józef Sołtan (1508-1522) został wówczas poproszony o dokonanie pochówku królowej Heleny na początku 1513 roku w Wilnie, a w roku następnym do odbioru przysięgi wierności królowi od możnowładztwa i bojarów prawosławnych przed zbliżającą się wojną z Wielkim Księstwem Moskiewskim².

W 1514 roku w obradach synodu wileńskiego uczestniczył wysłannik patriarchy carogrodzkiego Pachomiusza I (1504-1513), archimandryta leszczyński, Filipos³. Oprócz niego w soborze brali udział: metropolita Józef Sołtan, biskup smoleński Warsonofiusz (1508-1514), włodzimiersko -brzeski Pafnucy (1511-1522), turowsko-brzeski Arseniusz (1509-1518). Pod ustaleniami soborowymi podpisali się jeszcze: archimandryta wileński Antoni, ihumen wileński Efraim, protopop nowogródzki - Nektow z cerkwi św. Mikołaja, proboszczowie wileńscy: Iwan Kasza - z cerkwi św. Michała, Ifenti Masło - z cerkwi św. Jerzego, Roman

\footnotetext{
A. Mironowicz, Sobory wileńskie 1509 i 1514 roku, („Synody Cerkwi prawosławnej w I Rzeczypospolitej”). „Latopisy Akademii Supraskiej”, vol. V, pod red. M. Kuczyńskiej i U. Pawluczuk, Białystok 2014, s. 71-82.

2 H. Lulewicz, Sołtan Józef, „Polski Słownik Biograficzny”, t. LX, z. 3, Warszawa-Kraków 2001, s. 360; Б. Н. Флоря, Иосиф II, [w:] Православная энииклопедия, т. XXVI, Москва 2011, s. 14-17.

3 Археографический сборник документов, относящихся к истории Северо-Западной Руси, издаваемьй при управлении Виленского учебного округа (dalej: АСД), т. I, Вильно 1867, s. 39-41; A. Łapiński, Zygmunt Stary a Kościół prawosławny, Warszawa 1937, s. 7.
}

- z cerkwi św. Paraskiewy Piątnickiej - i diak metropolity Jezow Fedkowicz ${ }^{4}$.

Wbrew panującej w literaturze naukowej opinii podczas soboru nie wspomniano o planach unii kościelnej5. Metropolita Józef zrzekł się na soborze wielu praw do monasteru supraskiego. Klasztor został zwolniony z wszelkich opłat na rzecz metropolii ${ }^{6}$. Zapisano również, że ihumen powinien przybywać do metropolity tylko w wyjątkowych sytuacjach - na przykład, kiedy zostanie zawezwany

\footnotetext{
АСД, т. I, s. 39, 41.

„Русская Историческая Библиотека”, т. IV, Санкт-Петербург 1878, s. 5-18; A. Łapiński, Zygmunt Stary a Kościół prawosławny, s. 21-22; A. Mironowicz, Kościół prawosławny w państwie Piastów i Jagiellonów, Białystok 2003, s. 210-211. O przywiązaniu metropolity Józefa Sołtana do prawosławia świadczy fakt, że nuncjusz papieski Zachariasz Forreri wysłany przez papieża Leona X (1513-1521) do Wilna w 1521 r. w sprawie kanonizacji św. Kazimierza, nazywa metropolitę „wielkim schizmatykiem”. J. Daniłowicz, Skarbiec dyplomów papieskich, książęcych, uchwał narodowych, postanowień różnych władz $i$ urzędów posługujących do krytycznego wyjaśnienia dziejów Litwy, Rusi Litewskiej i ościennych innych krajów, t. II, Wilno 1862, s. 263-265; A. Mironowicz, Największa fundacja Aleksandra Chodkiewicza. Spór o charakter fundacji, [w:] Władza i prestiz. Magnateria Rzeczypospolitej w XVI-XVIII wieku, red. J. Urwanowicz, Białystok 2003, s. 529-550.

6 Biblioteka Muzeum Narodowego im. Czartoryskich w Krakowie, Zbiór dokumentów pergaminowych, nr 76, (MNK 541/8), k. 1; Николай (Далматов), Супрасльский Благовещенский монастырь, СанктПетербург 1892, s. 28; Summariusz dokumentów do dóbr supraskich, opr. A. Mironowicz, Białystok 2009, s. 57, 139; A. Mironowicz, A. Mironowicz, Powstanie monasteru supraskiego, „Białostockie Teki Historyczne”, nr 10, Białystok 2012, s. 25; tenże, O początkach monasteru supraskiego i jego fundatorach, Supraśl 2013, s. 34-35.
} 
do udziału w soborze. Metropolita zachował jedynie prawo nadzoru duchowego, żeby ihumen i mnisi żyli zgodnie $\mathrm{z}$ regułą klasztorną ustanowioną przez patriarchę Joachima w 1505 roku. Ponadto metropolita zachował prawo sądzenia ihumena za naruszenie reguły zakonnej i prawo udzielania błogosławieństwa nowemu przełożonemu klasztoru, wybranemu przez brać zakonną. Prawo sądzenia mnichów i nadzór nad ich postępowaniem przeszły w ręce ihumena monasteru? ${ }^{7}$. Przywilej ten został nadany klasztorowi supraskiemu na zakończenie soboru wileńskiego, 5 lutego 1514 roku, co dodatkowo podnosiło prestiż i rangę monasteru. Decyzja metropolity kijowskiego była podyktowana obawą przed ingerencją w życie klasztorne następnych metropolitów i faktem, że monaster supraski był klasztorem patriarszym.

Podczas obrad 1514 roku doszło też do kanonizacji Elizeusza (Jelisieja), archimandryty monasteru ławryszewskiego ${ }^{8}$. Biografia świętego wzbudza wiele kontrowersji historycznych. Badacze łączą osobę świętego z synem Mendoga (1200-1263) - Wojsiełkiem (1230-1267) - lub z synem księcia litewskiego Treinota (1263-1265) Rimunta, który miał przyjąć na chrzcie imię Ławr lub Laurencjusz?

W literaturze naukowej powszechnie uważa się, że klasztor Zaśnięcia NMP nad rzeką Niemen powstał w wyniku starań syna Mendoga Wojsiełka, księcia nowogródzkiego. Według tej hipotezy najpierw Wojsiełk przyjął na Wołyniu (Uhrowie) stan zakonny, a następnie w 1261 roku założył monaster nad Niemnem w Ławryszewie. Podczas pobytu w monasterze ławryszewskim książę dowiedział się o śmierci swych braci i w obawie o życie udał się do Pińska. Wojsiełk mnich po bratobójczych walkach między książętami litewskimi, przy pomocy wojsk pińskich i nowogródzkich, objął władzę na Litwie (1263-1267) ${ }^{10}$. Z kolei Szwarno (1267-1269), młodszy syn Daniela Romanowicza, ożeniony z siostrą Wojsiełka, objął rządy nad Rusią Czarną ${ }^{11}$. Po kil-

Oryginał jest przechowywany w: Archiwum Państwowe w Krakowie, Oddział na Wawelu, Zespół 29/630, Archiwum Młynowskie Chodkiewiczów (dalej - AP w Krakowie, AMCh), nr 35, k. 4; nr 36, k. 10, 141-142; „Вестник Западной России”, г. V, кн. VII, т. I, Вильно 1867, s. 15; Aкты, издаваемые комиссиею, высочайще учрежденною для разбора древних актов в Вильне (dalej АВАК), т. I, Вильно 1865, s. 38-42; Summariusz dokumentów do dóbr supraskich..., s. 57; А. Белецкий, Митрополить Іосифг II Солтанъ и отночение его къ Супрасльскому монастырю, Вильна 1899, s. 29-30.

8 A. W. Kojałowicz, Miscellanea rerum ad statum ecclesiasticum in magno Lituaniae ducato pertinentium, Vilnae 1650, s. 8; I. Stebelski, Dwa wielkie światła na horyzoncie połockim z cieniów zakazanych powstające czyli żywoty śs. Panien i matek Ewfrozyny i Parascewii zakonnic ihegumenij..., t. I., Lwów 1866, s. 111, przyp. 1; Ипатьевская летопись, [w:] Полное собрание русских летописей (dalej: ПСРЛ), т. II, Москва 1843, kol. 830-831, 858-869; Макарий, митроп., История Русской Церкви, т. IX, Санкт-Петербург 1879, s. 176, 177; K. Chodynicki, Kościót prawosławny a Rzeczpospolita Polska. Zarys historyczny (1385-1632), Warszawa 1934, s. 171, 172; A. Łapiński, Zygmunt Stary a Kościót prawosławny, s. 11-17, 20-24; A. Mironowicz, Kościół prawosławny w państwie Piastów i Jagiellonów..., s. 210.

9 Г. Киприянович, Исторический очерк Православия, католичества и унии в Белоруссии и Литве, Вильно 1895, s. 11-12.

10 ПСРЛ, т. II, s. 861; М. Ермаловиіч, Старажытная Беларусь, Мінск 1990 , s. 324.

11 Летописеи, великих князей титовских, ПСРЛ, т. XXXV, Москва 1980, s. 130; И. Данилович, О литовских летописях, „Журнал Министерства народного просвещеяия", 1840, №11, s. 70-114; Ф. Н. Добрянский, Описание рукописей Виленской публичной библиотеки, ku latach sprawowania władzy (w 1267 r.) Wojsiełk przekazał rządy na Litwie Szwarnie, a sam udał się do klasztoru w Uhrowsku. Właśnie wówczas pojawiła się realna szansa wprowadzenia chrześcijaństwa na Litwie. Wojsiełk był wyznawcą prawosławia i dążył do uporządkowania spraw wewnętrznych w państwie. $\mathrm{W}$ tym celu nawet na pewien czas porzucił monaster i zajął się sprawami kraju, próbując z prawosławia uczynić religię państwową. Decyzje księcia Wojsiełka zaostrzyły jego stosunki z książętami halicko-włodzimierskimi. Książę halicki Mścisław zamordował Wojsiełka za przekazanie Litwy Szwarnie. Szwarno, gorliwy wyznawca prawosławia, nie zamierzał ulec książętom halickim i kontynuował politykę chrystianizacji ziem litewskich.

Zabójstwo Wojsiełka pogorszyło stosunki rusko-litewskie. Trojden, który objął rządy na Litwie po śmierci Szwarna w 1269 r., prowadził niechętną politykę wobec Rusi ${ }^{12}$. Przejęcie władzy przez Trojdena (1269-1281) przekreśliło plany ewangelizacyjne Kościoła prawosławnego na Litwie już na początku drugiej połowy XIII wieku ${ }^{13}$. Powyższe informacje całkowicie wykluczają hipotezę o założeniu monasteru w Ławryszewie przez księcia Wojsiełka i utożsamienie go ze św. Elizeuszem. Pobyt księcia nowogródzkiego w monasterze jest odnotowany dopiero w 1261 roku, kiedy świętego ławryszewskiego już tam nie było.

Szczegółowa analiza pracy Alberta Wijuka Kojałowicza Miscellanea rerum ad statum ecclesiasticum in magno Lituaniae ducato pertinentium i Latopisu hipackiego pozwoliła Aleksemu Mielnikowi ${ }^{14}$ na rekonstrukcję najbardziej prawdopodobnej historii życia Elizeusza Ławryszewskiego i dziejów zorganizowanego przezeń monasteru. W świetle najnowszych ustaleń Elizeusz pochodził z rodziny książąt litewskich i przed wstąpieniem do klasztoru miał na imię Romult lub Rymont. Był dworzaninem na dworach księcia Ryngolda (zm. 1219) i Mendoga (1200-1263). Na dworze książęcym w tajemnicy przyjął chrześcijaństwo, a następnie wyjechał, udając się w odludne miejsce, gdzie spotkał prawosławnego mnicha o imieniu Grzegorz. Z Grzegorzem około 1225 roku przybył do monasteru Zaśnięcia NMP nad rzeką Niemen, niedaleko Nowogródka ${ }^{15}$. Monaster powstał jeszcze w końcu XII wieku, w miejscu trudno dostępnym, otoczonym wodami i bagnami. Przypuszcza się, że jego założycielem był biskup turowski Laurencjusz (1182-1194) ${ }^{16}$.

церковнославянских и русских, Вильна 1882, s. 70; А. А. Шахматов, О Супрасльском списке западно-русской летописи, Санкт-Петербург 1901, s. 1-16; И. А. Тихомиров, О составе Западно-русских, так назыьвемьх Литовских летописей, „Журнал Министерства народного просвещения”, 1901, № 3, s. 1-36, № 5, s. 7-119; ПСРЛ, т. XVII, Санкт-Петербург 1907, s. 1-84; ПСРЛ, т. ХХХV, s. 36-67.

12 B. Włodarski, Polska i Ruś 1194-1340, Warszawa 1966, s. 150, 151.

13 A. Mironowicz, Kościół prawosławny w państwie Piastów i Jagiellonów..., s. 102-104.

14 А. А. Мельников, Путь непечален. Исторические свидетельства о святости Белой Руси, Минск 1992, s. 140-142.

15 А. В., Кузьмин, Елисей, „Православная энциклопедия”, т. XVIII, Москва 2008, s. 406-407; A. Martynowicz, Sobory lokalne Kościoła prawosławnego na ziemiach polsko-litewsko-ruskich do końca XVI wieku, Praca doktorska napisana pod kierunkiem prof. A. Mironowicza, Białystok 2013, maszynopis, s. 137-140.

16 A. Mironowicz, Biskupstwo turowsko-pińskie w XI-XVI wieku, Białystok 2011, s. 176-178 
Możliwe, że to od imienia władyki monaster uzyskał swoją nazwę. Według niektórych hagiografów, Elizeusz był uczniem niezwykle szanowanego św. Laurencjusza Zatwornika, biskupa turowskiego (1182-1194) ${ }^{17}$. O tych związkach wspomina fragment jego troparionu „3 Лаврентием чудным подвизалься Елисей”.

Mnich asceta był więc w Ławryszewie już w 1225 roku. Elizeusz początkowo prowadził życie pustelnicze. Informacja o jego ascetycznym życiu zaczęła przyciągać wielu mnichów. To dla nich święty wybudował cerkiew Wniebowstąpienia Pańskiego ${ }^{18}$, a następnie został przełożonym zgromadzenia na początku lat czterdziestych XIII wieku. Wraz z innymi mnichami Elizeusz Ławryszewski wybudował inne drewniane budynki klasztorne ${ }^{19}$. Jako pierwszy przełożony monasteru Elizeusz znany był z ascetycznego życia duchowego. Prawdopodobnie od św. Laurencjusza przyjął dar walki z biesami. Jego pełen wyrzeczeń mnisi żywot został przerwany przez opętanego młodzieńca, który 23 października 1250 roku zamordował ihumena. Po dotknięciu zabitego mnicha młodzieniec został uzdrowiony, a u grobu ascety znajdującego się w cerkwi monasterskiej zaczęły dokonywać się liczne cuda. Za jego wstawiennictwem wielu chorych doznawało uzdrowień. Uzdrowienia dotyczyły zwłaszcza osób opętanych.

Elizeuszowi przypisuje się obronę monasteru ławryszewskiego przed najazdem Tatarów na początku XVI wieku. $^{20}$ Kanonizacja nastąpiła po wydarzeniu z 1508 roku, kiedy Tatarzy zorganizowali kolejną wyprawę na Nowogródek. Najeźdźcy zgromadzili konnicę w okolicach monasteru i zamierzali zająć klasztor. Według legendy, napastnicy zobaczyli, że cały monaster jest napełniony wojskiem, choć nie było w nim ani jednego żołnierza. To wsta-

\footnotetext{
7 Bibliografia władyki Laurencjusza została opisana w Paterykonie Kijowsko-Pieczerskim i w Żywotach Świętych Dymitra Rostowskiego. Źródła nie dają możliwości ustalenia daty, miejsca urodzenia biskupa turowskiego, ani jego świeckiego imienia. Przypuszcza się, że urodził się on w Turowie w latach trzydziestych XII w. Początkowo Laurencjusz był mnichem monasteru św. św. Borysa i Gleba w Turowie, a następnie przybył do Ławry Kijowsko-Pieczerskiej. Kiedy ihumen odmówił mu błogosławieństwa na życie w samotności w pieczarach klasztoru, mnich zdecydował się na życie w zamknięciu w swojej celi w monasterze św. Dymitra Sołuńskiego w Kijowie. Po kilkuletnim pobycie w monasterze Laurencjusz powrócił do Ławry Kijowsko-Pieczerskiej. Tam zamieszkał w jednej z pieczar klasztoru. W obu klasztorach dał się poznać jako człowiek modlitwy, gorliwy kaznodzieja i cudotwórca. Był znany z uzdrowień ludzi opanowanych przez demony. A. А. Мельников, Путь непечален., s. 133-134. Laurencjusz biskupem turowskim został w 1182 r. Niestety, nie mamy innych informacji o działalności władyki turowskiego, albowiem źródła nie wspominają imion ordynariuszy diecezji aż do 1390 r. Według tradycji, zmarły biskup turowski pochowany został na cmentarzu monasteru św. św. Borysa i Gleba. Decyzją władz cerkiewnych, Laurencjusz, jako były zatwornik Ławry Kijowsko-Pieczerskiej, został przeniesiony do pieczary św. Antoniego w Kijowie. A. А. Мельников, Путь непечален., s. 72-73; A. Mironowicz, Biskupstwo turowsko-pińskie w XI-XVI wieku..., s. 43, 176-178.

18 Г. Киприянович, Исторический очерк Православия., s. 11-12. 19 Описание церквей и приходов Минской епархии, вып. VI, Минск 1879, s. 75; И. Н. Слюнькова, Монастьри восточной и западной традиций, Москва 2002, s. 39.

20 A. W. Kojałowicz, Miscellanea rerum ad statum ecclesiasticum in magno Lituaniae ducato pertinentium, s. 8, 36; Ипатьевская летопись..., ПСРЛ, т. II, kol. 830-831, 858-869; A. Mironowicz, Biskupstwo turowsko-pińskie w XI-XVI wieku, s. 176.
}

wiennictwo ihumena Elizeusza miało skłonić najeźdźców do odwrotu.

Informacje o cudach u grobu mnicha ascety znane były na całym obszarze Wielkiego Księstwa Litewskiego. Cuda dokonane za sprawą Elizeusza skłoniły metropolitę Sołtana do zwołania soboru i kanonizacji mnicha. Zwolennikiem kanonizacji był archimandryta ławryszewski, Ignacy, blisko związany z Józefem Sołtanem. Archimandryta ławryszewski był również członkiem sądu metropolitarnego w Wilnie w 1511 roku i już wówczas występował w sprawie kanonizacji Elizeusza Ławryszewskiego. Ostatecznie ihumen Elizeusz został uznany za świętego na soborze wileńskim 1514 roku, a 23 października, dzień śmierci świętego, ustanowiono dniem jego liturgicznej pamięci. Z okazji tej kanonizacji oprawiona została ewangelia ławryszewska ${ }^{21}$.

21 Д. П. Огицкий, Великий князь Войщелк (страница из истории православия в Литве), „Богословские Труды”, Москва 1983, s. 171-196. Z XIV wieku pochodzi też słynna ewangelia $\mathrm{z}$ monasteru ławryszewskiego. Na temat ewangeliarza pisali $\mathrm{m}$. in. T. Friedelówna, Ewangeliarz Ławryszewski. Monografia zabytku, Wrocław-WarszawaKraków 1974; М. Нікалаеў, Палата кнігапісная: Рукапісная кніга на Беларусі у Х-XVIII стагоддзях, Мінск 1993, s. 54, 69, 134, 162, 199; Г. Киприянович, Исторический очерк Православия., s. 22. Ewangelia ławryszewska na pierwszej stronie miała namalowaną postać archanioła Michała, opiekuna władzy książęcej. Z zapisów na kartach ewangeliarza najwcześniejsze są Koriata, czyli Michała Giedyminowicza (zm. 1330), Aleksandra Włodzimierzowicza, syna Włodzimierza Olgierdowicza (zm. 1454) i Dymitra Korybuta Olgierdowicza (1350-1404). Ewangeliarz składa się z dwóch części: czytań ewangelii od Paschy do Wielkiej Soboty (s. 1-320) oraz czytań ewangelii od 1 września do końca sierpnia (s. 320-366). Według Mikołaja Nikołajewa, w ewangeliarzu wykorzystano 98\% ewangelii św. Mateusza, 97\% św. Marka, 97\% św. Łukasza, 93\% św. Jana Teologa (Ewangelisty). Na stronach 28-30 znajdują się śpiewane kanony, m. in. Kanon i płacz św. Bogurodzicy. Przedstawiona tam hymnografia nawiązuje bezpośrednio do wzorców bizantyjskich. Ten fragment ewangeliarza został wykonany przez mnicha Hioba (Иова). М. Нікалаеў, Палата кнігапісная: Рукапісная кніга на Беларусі ў X-XVIII cmazoддзяx, s. 69. Otwarte pozostaje pytanie, czy był on również autorem całego rękopisu. Bogato zdobione okładki do ewangeliarza zostały wykonane na początku XVI w., w okresie kanonizacji założyciela monasteru Jelisieja Ławryszewskiego. Ibidem, s. 72, 134

W monasterze ławryszewskim powstał też pełny cykl Prologu. Prolog to cerkiewno-pouczający zbiór, prototypem którego były greckie menologiony (минеu) i synaksary (żywoty świętych). Księga obejmował żywoty świętych, pouczenia, pouczające opowieści i opowiadania. Materiał do czytania (opowieści, kazania, żywoty i pouczenia) był rozłożony na 366 dni. W monasterze pracowała nad nim grupa kopistów pod kierunkiem diakona Joachima za czasów wojewody nowogródzkiego Jana Janowicza Zabrzezińskiego w 1512 r. Na początku XVI w. księga trafiła do Wilna, przywieziona przez archimandrytę ławryszewskiego Ignacego. Inny Prolog został wykonany przez diakona Joachima $z$ katedralnego soboru św. św. Borysa i Gleba w Nowogródku na zamówienie wojewody Zabrzezińskiego (1509-1530). Treść manuskryptu sprawdzał diakona wileńskiej cerkwi św. Jerzego - Ignacy - późniejszy archimandryta ławryszewski. Przekazał on rękopis metropolicie kijowskiemu Józefowi Sołtanowi w Wilnie w $1511 \mathrm{r}$. Oprawę rękopisu wykonał mnich Porfiriusz z Lubczy w 1512 r. W 1514 r. rękopis został przekazany do monasteru supraskiego. Tu znajdował się do 1852 r. Następnie wysłano go do archimandryty Pawła Dobrochotowa (późniejszego biskupa pskowskiego i ryskiego). Przed 1882 r. trafił do Wileńskiej Biblioteki Publicznej. W 1915 r. został wywieziony do Moskwy lub Jarosławia. Do Wilna powrócił w latach 1945-1946 i trafił do Biblioteki Akademii Nauk Litwy im. Wróblewskich. Ibidem, s. 93; Rękopisy supraskie $w$ zbiorach krajowych i obcych, pod red. A. Mironowicz, Białystok 2014, s. 197-201. Podobne manuskrypty były w monasterze Zaśnięcia NMP pod Pińskiem. Inwentarz monasteru leszczyńskiego z 1588 r. wymienia dwa Prologi na wszystkie dwanaście miesięcy. „Минская Старина”, вып. I, Минск 1909, s. 118. 
Relikwie świętego, które znajdowały się w monasterze ławryszewskim były dostępne wiernym do końca XVII wieku. Podczas wojenny ze Szwecją z 1706 roku relikwie ukryto w ziemi, a klasztor zrujnowano. W latach 1775-1780 monaster został odbudowany, zaś w 1836 roku cerkiew monasterską przekształcono w parafialną.

Ponownie reaktywowanie monasteru nastąpiło na mocy decyzji metropolity mińskiego i turowskiego Mitrofana (Karsnopolskiego) 14 lipca 1913 roku. Wybudowano wówczas cerkiew św. Elizeusza. W 1915 roku w rezultacie najazdu wojsk niemieckich cerkiew i resztki budynków klasztornych spłonęły. Po pożarze relikwie Elizeusza Ławryszewskiego nie zostały odnalezione ${ }^{22}$. Pomimo nie odnalezienia relikwii kult św. Elizeusza jest nadal bardzo popularny na ziemiach białoruskich i litewskich.

\section{Podsumowanie}

Sobór prawosławny w Wilnie kanonizował w 1514 roku Elizeusza Ławryszewskiego i przez tę kanonizację doprowadził do rozwoju jego kultu na całym obszarze Wielkiego Księstwa Litewskiego. Sobór podkreślił też rolę

22 Арх. Николай, Историко-статистическое Описание Минской иерархии, Санкт-Петербург 1864, s. 131; А. В., Кузьмин, Елисей, s. 407. świętych męczenników w życiu Cerkwi a zwłaszcza św. Elizeusza i męczenników wileńskich, Antoniego, Jana i Eustachego. Żywot świętych Antoniego, Jana i Eustachego był powszechnie znany na terenie Wielkiego Księstwa Litewskiego. Męczeństwo świętych wileńskich było również znane na terenie Bizancjum. Patriarcha carogrodzki Filoteusz Czerwony (1354-1355, 1364-1376) sprowadził w 1374 roku relikwie świętych wileńskich do Konstantynopola. Z pole-

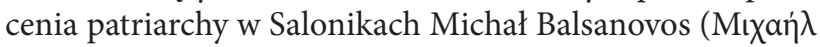

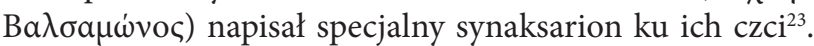
Po upadku Cesarstwa Bizantyjskiego staraniem metropolitów kijowskich relikwie męczenników powróciły w końcu XV wieku z Konstantynopola do Wilna ${ }^{24}$.

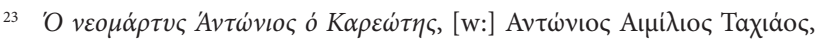

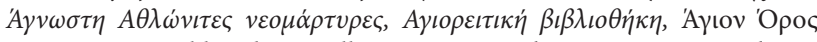
2006, s. 25; F. Miklosich, I. Müller, Acta Patriarchatus Constantinopolitani, vol. I, Vindobonae 1860, s. 523-524; D. Baronas, Trys Vilniaus Kankiniai. Gyvenimas ir Istorija, Vilnius 2000, s. 200-243. Synaksarion, synaksariusz (gr. $\Sigma v v \alpha \xi \dot{\alpha} \rho ı v$, od słowa $\sigma v v \alpha \gamma \varepsilon l v$ - zbierać razem) - księga, zawierająca krótkie życiorysy świętych na każdy dzień roku liturgicznego (w roku przejściowym).

24 А. И. Рогов, Литературные связи Белоруссии с балканскими странами в XV-XVI вв., [в:] Славянские литературы. VIII Международный съезд славистов, Загреб-Любляна, сентябрь 1978 г. Доклады советской делегации, Москва 1978, s. 188-189; A. Mironowicz, Święci w Kościele prawosławnym na Białorusi, [w:] Wilno i kresy pótnocno-wschodnie, t. I., Historia i ludzkie losy, red. E. Feliksiak, A. Mironowicz, Białystok 1996,

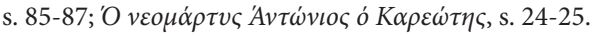

\section{Bibliografia}

\section{Źródła rękopiśmienne}

Archiwum Państwowe w Krakowie, Oddział na Wawelu, Zespół 29/630, Archiwum Młynowskie Chodkiewiczów, nr-y: 35-36.

Biblioteka Muzeum Narodowego im. Czartoryskich w Krakowie, Zbiór dokumentów pergaminowych, nr 76, (MNK 541/8).

\section{Źródła drukowane}

Акты, издаваемые комиссиею, высочайше учрежденною для разбора древних актов в Вильне, т. І, Вильно 1865.

Археографический сборник документов, относящихся кистории Северо-Западной Руси, издаваемый при управтении Виленского учебного округа, т. I, Вильно 1867. Ипатьевская летопись, [w:] Полное собрание русских летописей, т. II, Москва 1843,

A. W. Kojałowicz, Miscellanea rerum ad statum ecclesiasticum in magno Lituaniae ducato pertinentium, Vilnae 1650.

Летописеи, великих князей титовских, [w:] Полное собрание русских летописей, т. XXXV, Москва 1980.

„Минская Старина”, вып. I, Минск 1909.

Описание иерквей и приходов Минской епархии, вып. VI, Минск 1879.

Полное собрание русских тетописей, т. XVII, Санкт-Петербург 1907.

Rękopisy supraskie w zbiorach krajowych i obcych, pod red. A. Mironowicz, Białystok 2014.
„Русская Историческая Библиотека”, т. IV, Санкт-Петербург 1878.

Stebelski I., Dwa wielkie światła na horyzoncie połockim $z$ cieniów zakazanych powstające czyli żywoty śs. Panien i matek Ewfrozyny i Parascewii zakonnic i hegumenij..., t. I., Lwów 1866.

Summariusz dokumentów do dóbr supraskich, opr. A. Mironowicz, Białystok 2009.

„Вестник Западной России”, г. V, кн. VII, т. I, Вильно 1867.

\section{Literatura}

Арх. Николай, Историко-статистическое Описание Минской иерархии, Санкт-Петербург 1864.

Baronas D., Trys Vilniaus Kankiniai. Gyvenimas ir Istorija, Vilnius 2000.

Белецкий А., Митрополить Іосифъ ІІ Солтанъ и отношение его къ Супрасльскому монастырю, Вильна 1899,

Chodynicki K., Kościół prawosławny a Rzeczpospolita Polska. Zarys historyczny (1385-1632), Warszawa 1934.

Daniłowicz J., Skarbiec dyplomów papieskich, książęcych, uchwał narodowych, postanowień różnych władz i urzędów posługujących do krytycznego wyjaśnienia dziejów Litwy, Rusi Litewskiej i ościennych innych krajów, t. II, Wilno 1862.

Данилович И., О титовских тетописях, „Журнал Министерства народного просвещеяия", 1840, №11. 
Добрянский Ф. Н., Описание рукописей Виленской публичной библиотеки, иерковнославянских и русских, Вильна 1882.

Ермаловиіч М., Старажытная Беларусь, Мінск 1990.

Friedelówna T., Ewangeliarz Lawryszewski. Monografia zabytku, Wrocław-Warszawa-Kraków 1974.

Флоря Б. Н., Иосиф II, [w:] Православная энциклопедия, т. XXVI, Москва 2011.

Киприянович Г., Исторический очерк Православия, католичества и унии в Белоруссии и Литве, Вильно 1895.

Кузьмин А. В., Елисей, „Православная энциклопедия”, т. XVIII, Москва 2008.

Lulewicz H., Sołtan Józef, „Polski Słownik Biograficzny”, t. LX, z. 3, Warszawa-Kraków 2001.

Łapiński A., Zygmunt Stary a Kościót prawosławny, Warszawa 1937.

Макарий, митроп., История Русской Церкви, т. IX, Санкт-Петербург 1879.

Martynowicz A., Sobory lokalne Kościoła prawosławnego na ziemiach polsko-litewsko-ruskich do końca XVI wieku, Praca doktorska napisana pod kierunkiem prof. A. Mironowicza, Białystok 2013, maszynopis.

Мельников А. А., Путь непечален. Исторические свидетельства о святости Белой Руси, Минск 1992.

Miklosich F., Müller I., Acta Patriarchatus Constantinopolitani, vol. I, Vindobonae 1860.

Mironowicz A., Biskupstwo turowsko-pińskie w XI-XVI wieku, Białystok 2011.

Mironowicz A., Kościót prawosławny w państwie Piastów i Jagiellonów, Białystok 2003.

Mironowicz A., Największa fundacja Aleksandra Chodkiewicza. Spór o charakter fundacji, [w:] Władza i prestiz. Magnateria Rzeczypospolitej w XVI-XVIII wieku, red. J. Urwanowicz, Białystok 2003.
Mironowicz, O początkach monasteru supraskiego i jego fundatorach, Supraśl 2013.

Mironowicz A., Powstanie monasteru supraskiego, „Białostockie Teki Historyczne", nr 10, Białystok 2012.

Mironowicz A., Sobory wileńskie 1509 i 1514 roku, („Synody Cerkwi prawosławnej w I Rzeczypospolitej”). „Latopisy Akademii Supraskiej”, vol. V, pod red. M. Kuczyńskiej i U. Pawluczuk, Białystok 2014.

Mironowicz A., Święci $w$ Kościele prawosławnym na Białorusi, [w:] Wilno i kresy pótnocno-wschodnie, t. I., Historia i ludzkie losy, red. E. Feliksiak, A. Mironowicz, Białystok 1996.

Николай (Далматов), Супрасльский Благовещенский монастырь, Санкт-Петербург 1892.

Нікалаеў М., Палата кнігапісная: Рукапісная кніга на Бела-

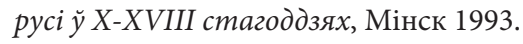

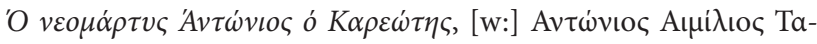

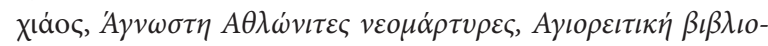
$\theta \dot{\eta} \kappa \eta$, 'Aүıоv'Орос 2006.

Огицкий Д. П., Великий князь Войшелк (страница из истории православия в Литве), „Богословские Труды”, Москва 1983.

Рогов А. И., Литературные связи Белоруссии с балканскими странами в XV-XVI вв., [в:] Славянские литературы. VIII Международный съезд славистов, Загреб-Любляна, сентябрь 1978 г. Доклады советской делегации, Москва 1978.

Слюнькова И. Н., Монастьри восточной и западной традиций, Москва 2002

Шахматов А. А., О Супрасльском списке западно-русской летописи, Санкт-Петербург 1901.

Тихомиров И. А., О составе Западно-русских, так называемых Литовских летописей, „Журнал Министерства народного просвещения”, 1901, № 3-5.

Włodarski B., Polska i Ruś 1194-1340, Warszawa 1966.

Rozmiar artykułu: 0,7 arkusza wydawniczego 
ISSN 1508-7719

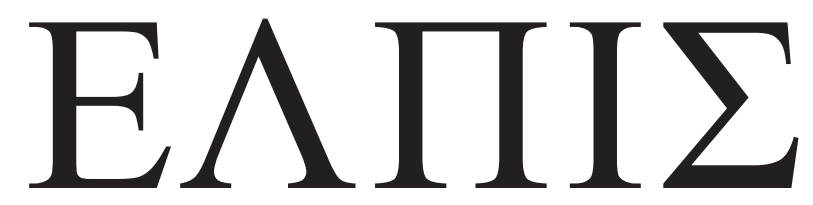

CZASOPISMO TEOLOGICZNE KATEDRY TEOLOGII PRAWOSŁAWNEJ UNIWERSYTETU W BIAŁYMSTOKU

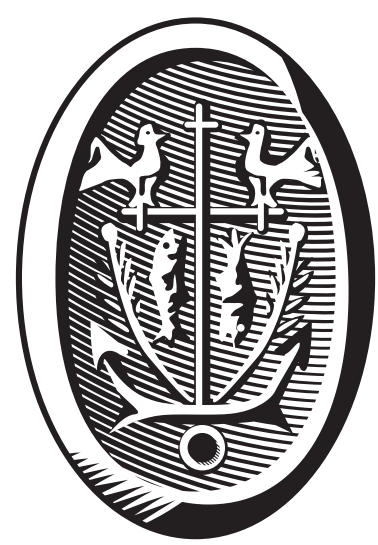

ADRES REDAKCJI

15-097 Białystok, ul. M. Skłodowskiej-Curie 14 tel. 85 745-77-80, e-mail: redakcja@elpis.edu.pl www.elpis.uwb.edu.pl 